\title{
FAKTOR YANG BERHUBUNGAN DENGAN KEJADIAN ANEMIA DALAM KEHAMILAN TRIMESTER III DI WILAYAH KERJA PUSKESMAS MAPANE
}

\author{
Factors Related to The Incidence of Anemia in The Third Trimester of Pregnancy \\ in The Work Area of The Mapane Community Health Center
}

\author{
Nilda Yulita Siregar ${ }^{1 *}$, Silfana Hiola ${ }^{1}$, Nurfatimah ${ }^{1}$ \\ ${ }^{1}$ Jurusan Kebidanan Poltekkes Kemenkes Palu \\ *(email Korespondensi: nildayulitasiregar@gmail.com)
}

\begin{abstract}
ABSTRAK
Anemia pada ibu hamil merupakan masalah kesehatan terkait dengan insidennya yang tinggi dan komplikasi yang dapat timbul baik pada ibu hamil maupun janinnya. Penelitian ini bertujuan untuk mengetahui faktor-faktor yang berhubungan dengan kejadian anemia dalam kehamilan trimester III di wilayah kerja Puskesmas Mapane. Penelitian ini menggunakan metode survey analitik dengan desain cross sectional. Populasi dalam penelitian ini adalah ibu hamil trimester 3 yang ada di wilayah kerja Puskesmas Mapane. Sampel dalam penelitian ini sebanyak 39 orang, teknik penentuan sampel secara total sampling. Hasil penelitian didapatkan 36 orang $(92,3 \%)$ responden yang mengalami anemia ringan, ibu berumur 20-35 tahun 29 orang $(96,7)$, pendidikan SMA 14 orang $(100 \%)$, multigravida 28 orang $(93,3 \%)$, paritas kategori primipara 8 orang (100\%), Ekonomi di atas UMK 13 orang (100\%) dan konsumsi tablet Fe tidak patuh 2 orang (100\%). Hasil temuan bivariat uji chi-square didapatkan tidak ada hubungan yang bermakna antara umur ibu dengan kejadian anemia $(p=0,062)$, tidak terdapat hubungan yang bermakna antara pendidikan dengan kejadian anemia $(\mathrm{p}=0,491)$, tidak terdapat hubungan yang bermakna antara gravida dengan kejadian anemia $(\mathrm{p}=0,661)$, tidak terdapat hubungan yang bermakna antara paritas dengan kejadian anemia $(\mathrm{p}=0,784)$, tidak terdapat hubungan yang bermakna antara ekonomi dengan kejadian anemia $(\mathrm{p}=0,202)$, tidak terdapat hubungan yang bermakna antara konsumsi tablet $\mathrm{Fe}$ dengan kejadian anemia $(\mathrm{p}=0,675)$.Sehingga dapat disimpulkan, tidak terdapat hubungan yang bermakna antara umur, pendidikan, gravida, paritas, ekonomi dan konsumsi teablet Fe dengan kejadian anenia pada ibu hamil.
\end{abstract}

\section{Kata Kunci: Anemia; Gravida; Paritas; Konsumsi Tablet Fe}

\section{ABSTRACT}

Anemia in pregnant women is a health problem associated with a high incidence and complications that can arise both in pregnant women and their fetuses. This study aims to determine the factors associated with the incidence of anemia in the third trimester of pregnancy in the Mapane Community Health Center. This study uses analytic survey method with cross sectional design. The population in this study was 3rd trimester pregnant women in the Mapane Community Health Center. The sample in this study were 39 people, the technique of determining the sample in total sampling. The results found 36 people (92.3\%) of respondents who experienced mild anemia, mothers aged 20-35 years 29 people (96.7), high school education 14 people (100\%), multigravida 28 people (93.3\%), primacy parity category of 8 people (100\%), Economy above 13 people UMK (100\%) and consumption of Fe tablets not compliant 2 people (100\%). The results of the bivariate chi-square test that there is no significant relationship between maternal age with the incidence of anemia $(p=0.062)$, there is no significant relationship between education and the incidence of anemia $(p=0.491)$, there is no significant relationship between gravida and the incidence anemia $(p=0.661)$, there was no significant relationship between parity and anemia $(p=0.784)$, there was no significant relationship between the economy and anemia $(p=0.202)$, there was no significant relationship between consumption of Fe tablets with the incidence anemia $(p=0.675)$. So it can be concluded that there is no significant relationship between age, education, gravida, parity, economy and consumption of $F e$ teablet with the incidence of anemia in pregnant women.

Keywords: Anemia; Gravida; Parity; Take Fe tablets 


\section{PENDAHULUAN}

Anemia merupakan salah satu masalah kesehatan global yang banyak ditemukan di masyarakat terutama pada ibu hamil. Ibu hamil sangat rentan mengalami anemia, hal ini disebabkan oleh meningkatnya kebutuhan ibu akan zat besi seiring dengan bertambahnya usia kehamilan. Anemia pada ibu hamil merupakan masalah kesehatan terkait dengan insidennya yang tinggi dan komplikasi yang dapat timbul baik pada ibu hamil maupun janinnya. Anemia merupakan masalah kesehatan yang sering terjadi tapi sampai sekarang masih sulit untuk dihilangkan terutama anemia kekurangan zat besi pada saat hamil ${ }^{1}$.

Dampak negatif anemia terhadap ibu hamil dan janinnya yaitu abortus, hambatan tumbuh kembang janin dalam rahim, mudah terjadi infeksi dekompensasi kordis $(\mathrm{Hb}<6$ gr\%), mola hidatidosa, hiperemesis gravidarum, perdarahan antepartum, Ketuban Pecah Dini (KPD), terjadi kematian intrauteri, prematur, Berat badan lahir rendah (BBLR), kelahiran dengan anemia, dapat terjadi cacat bawaan dan bayi mudah mendapat infeksi sampai kematian perinatal ${ }^{2}$.

Anemia pada ibu hamil dapat meningkatkan risiko terjadinya keguguran, lahir sebelum waktunya, melahirkan bayi dengan Berat Badan Rendah (BBLR), lahir mati, dan kematian perinatal. Ibu hamil yang menderita anemia berat dapat mengalami kegagalan jantung yang berakibat terhadap kematian ${ }^{3}$.

Dari hasil uji penelitian Rizki Amartami dkk, diketahui bahwa pengetahuan, sikap, pola makan, jumlah anak, serta pelayanan kesehatan, maka dapat disimpulkan bahwa ada hubungan antara variabel bebas dengan kejadian anemia pada ibu hamil ${ }^{4}$.

Beberapa faktor yang dapat menyebabkan terjadinya anemia dalam kehamilan diantaranya umur, pendidikan, gravida, paritas, tingkat pendidikan, status ekonomi dan kepatuhan konsumsi tablet $\mathrm{Fe}^{5}$.

Menurut laporan World Health Organization (WHO), tahun 2014 beberapa negara memiliki AKI cukup tinggi seperti Afrika Sub-Saharan 179.000 jiwa, Asia Selatan 69.000 jiwa, dan Asia Tenggara 16.000 jiwa. Angka kematian ibu di negaranegara Asia Tenggara yaitu Indonesia 190 per 100.000 kelahiran hidup, Vietnam 49 per
100.000 kelahiran hidup, Thailand 26 per 100.000 kelahiran hidup, Brunei 27 per 100.000 kelahiran hidup, dan Malaysia 29 per 100.000 kelahiran hidup ${ }^{6}$.

World Health Organization (WHO) menyebutkan bahwa secara global prevalensi ibu hamil dengan anemia sebanyak 83,2\% sedangkan negara-negara di Asia tenggara memiliki prevalensi sebesar $97,8 \%$. Hal ini menunjukan bahwa prevalensi anemia pada ibu hamil di Asia tenggara melebihi nilai prevalensi secara global ${ }^{6}$.

Pada tahun 2012 di Indonesia didapati Angka Kematian Ibu (AKI) sebanyak 359/100.000 kelahiran hidup, jumlah ini bila dibandingkan dengan tahun 2015 terlihat ada penurunan yaitu 305/100.000 kasus? .

Angka Kematian Ibu (AKI) di Sulawesi Tengah sejak tahun 2011 sampai dengan tahun 2015 mengalami penurunan dari 221/100.000 menjadi 208/100.000 kelahiran hidup (Dinkes Sulteng, 2015). Pada tahun 2017 Angka Kematian Ibu (AKI) di kabupaten poso sebanyak 27,36/100.000 kelahiran hidup ${ }^{8}$.

Pada tahun 2018 di Kabupaten Poso ibu hamil berjumlah 5.111 dan kasus anemia pada ibu hamil mencapai 2.189 kasus anemia ringan dan 97 kasus anemia sedang ${ }^{8}$. Sesuai dengan data yang ada di wilayah kerja Puskesmas Mapane Kecamatan Poso Pesisir jumlah ibu hamil pada bulan Februari tahun 2019 berjumlah 122 ibu hamil dan tentang keadaan ibu hamil khususnya yang menderita anemia dalam kehamilan pada tahun 2018 dari 262 jumlah ibu hamil ditemukan sebesar 142 (54\%) kasus ibu hamil dengan anemia.

Penelitian ini bertujuan untuk mengetahui faktor yang berhubungan dengn kejadian anemia dalam kehamilan trimester III di Wilayah Kerja Puskesmas Mapane.

\section{METODE PENELITIAN}

Penelitian ini menggunakan metode survey analitik dengan desain cross sectional. Penelitian ini dilakukan di wilayah kerja puskesmas Mapane pada bulan April-Mei 2019. Populasi dalam penelitian ini adalah ibu hamil trimester 3 yang ada di wilayah kerja Puskesmas Mapane. Teknik pengambilan sampel dalam penelitian ini secara total sampling sebanyak 39 orang. Pengumpulan data dilakukan melalui pengisian kuesioner penelitian dan dari berbagai sumber untuk menunjang latar belakang yaitu berasal dari 
Dinas Kesehatan dan Puskesmas Mapane. Analisis data berupa analisa univariat dan bivariat dengan menggunakan uji chi square.

\section{HASIL}

\section{Analisis Univariat}

Dari tabel 1 menunjukkan bahwa persentase kejadian anemia ringan pada ibu hamil sebanyak 92,3\% (36). Ibu hamil umur 20-35 tahun sebanyak 76,9\% (30). Ibu yang berpendidikan SMA sebanyak $35,9 \%$ (14). Ibu multigravida sebanyak $76.9 \%$ (30). Ibu multivara sebanyak 56,4\% (22). Ibu hamil dengan ekonomi dibawah UMK sebanyak 66,7\% (26). Pada tabel 7 menunjukkan bahwa ibu hamil yang patuh mengkonsumsi tablet besi sebanyak $94,9 \%$ (37).
Tabel 1. Distribusi Klasifikasi Kejadian Anemia Dalam Kehamilan di Wilayah Kerja Puskesmas Mapane

\begin{tabular}{clrr}
\hline Variabel & \multicolumn{1}{c}{ Kategori } & n (39) & \multicolumn{1}{c}{$\%$} \\
\hline Kejadian & Tidak Anemia & 3 & 7,7 \\
Anemia & Anemia Ringan & 36 & 92,3 \\
\hline Umur & 20-35 tahun & 30 & 76,9 \\
& $>35$ tahun & 9 & 23,1 \\
\hline Pendidikan & SD & 5 & 12,8 \\
& SMP & 11 & 28,2 \\
& SMA & 14 & 35,9 \\
& PT/Diploma & 9 & 23,1 \\
\hline Gravida & Primigravida & 9 & 23,1 \\
& Multigravida & 30 & 76,9 \\
\hline Paritas & Primipara & 8 & 20,5 \\
& Multipara & 22 & 56,4 \\
& Grandemultipara & 1 & 2,6 \\
& Nullipara & 8 & 20,5 \\
\hline Ekonomi & Dibawah UMK & 26 & 66,7 \\
& Diatas UMK & 13 & 33,3 \\
\hline Konsumsi & Patuh (Minum) & 37 & 94,9 \\
Tablet Fe & Tidak Patuh & 2 & 5,1 \\
& (Tidak diminum) & & \\
\hline
\end{tabular}

Sumber : Data Primer, 2019

\section{Analisa Bivariat}

Hasil uji statistik variabel independen kaitanya dengan anemia pada ibu hamil seperti terlihat pada tabel dibawah ini:

Tabel 2 Distribusi Faktor-Faktor berhubungan dengan Kejadian Anemia dalam Kehamilan Trimester III di Wilayah Kerja Puskesmas Mapane

\begin{tabular}{|c|c|c|c|c|c|c|c|}
\hline \multirow{3}{*}{ Variabel Penelitian } & \multicolumn{4}{|c|}{ Kejadian anemia } & \multirow{2}{*}{\multicolumn{2}{|c|}{ Total }} & \multirow{3}{*}{$P$ value } \\
\hline & \multicolumn{2}{|c|}{ Tidak anemia } & \multicolumn{2}{|c|}{ Anemia ringan } & & & \\
\hline & $\mathrm{n}$ & $\%$ & $\mathrm{n}$ & $\%$ & $\mathrm{n}$ & $\%$ & \\
\hline \multicolumn{8}{|l|}{ Umur } \\
\hline $20-35$ & 1 & 3,3 & 29 & 96,7 & 30 & 100,0 & \multirow{2}{*}{0,062} \\
\hline$>35$ & 2 & 22,2 & 7 & 77,8 & 9 & 100,0 & \\
\hline \multicolumn{8}{|l|}{ Pendidikan } \\
\hline SD & 1 & 20,0 & 4 & 80,0 & 5 & 100,0 & \multirow{4}{*}{0,491} \\
\hline SMP & 1 & 9,1 & 10 & 90,9 & 11 & 100,0 & \\
\hline SMA & 0 & 0,0 & 14 & 100,0 & 14 & 100,0 & \\
\hline PT/Diploma & 1 & 11,1 & 8 & 88,9 & 9 & 100,0 & \\
\hline \multicolumn{8}{|l|}{ Gravida } \\
\hline Primigravida & 1 & 11,1 & 8 & 88,9 & 9 & 100,0 & \multirow{2}{*}{0,661} \\
\hline Multigravida & 2 & 6,7 & 28 & 93,3 & 30 & 100,0 & \\
\hline \multicolumn{8}{|l|}{ Paritas } \\
\hline Primipara & 0 & 0,0 & 8 & 100,0 & 8 & 100,0 & \multirow{4}{*}{0,784} \\
\hline Multipara & 2 & 9,1 & 20 & 90,0 & 22 & 100,0 & \\
\hline Grandemultipara & 0 & 0,0 & 1 & 100,0 & 1 & 100,0 & \\
\hline Nullipara & 1 & 12,5 & 7 & 87,5 & 8 & 100,0 & \\
\hline \multicolumn{8}{|l|}{ Ekonomi } \\
\hline Dibawah UMK & 3 & 11,5 & 23 & 88,5 & 26 & 100,0 & \multirow{2}{*}{0,202} \\
\hline Diatas UMK & 0 & 0,0 & 13 & 100,0 & 13 & 100,0 & \\
\hline \multicolumn{8}{|l|}{ Konsumsi tablet $\mathrm{Fe}$} \\
\hline Patuh (Minum) & 3 & 8,1 & 34 & 91,9 & 37 & 100,0 & 0,675 \\
\hline Tidak Patuh (Tidak minum) & 0 & 0,0 & 2 & 100,0 & 2 & 100,0 & \\
\hline
\end{tabular}


Tabel 2 menunjukan bahwa ibu hamil yang mengalami anemia ringan yang berumur 20-35 tahun sebesar 29 (96,7\%). Distribusi ibu hamil yang mengalami anemia ringan dengan pendidikan SMA sebesar 14 $(100,0 \%)$. Distribusi ibu hamil yang mengalami anemia ringan dengan multigravida sebesar $28 \quad(93,3,0 \%)$. Distribusi ibu hamil yang mengalami anemia ringan dengan paritas yang primipara dan grandemultipara sebesar $1 \quad(100,0 \%)$. Distribusi ibu hamil yang mengalami anemia ringan dengan ekonomi dibawah UMK sebesar $13(100,0 \%)$. Distribusi ibu hamil yang mengalami anemia ringan dengan tidak patuh minm tablet besi sebesar $2(100,0 \%)$.

\section{PEMBAHASAN}

\section{Hubungan Umur dengan Kejadian Anemia}

Hasil penelitian menunjukkan bahwa ibu hamil trimester III yang mengalami anemia ringan dengan kelompok usia 20-35 tahun yaitu sebanyak 29 responden (96,7\%). Berdasarkan hasil analisis Chi Square diperoleh nilai $p$-value sebesar 0,062 $(\mathrm{p}>0,05)$ yang berarti tidak ada hubungan antara umur ibu dengan kejadian anemia pada ibu hamil trimester III. Hasil penelitian ini sejalan dengan hasil Simbolon (2018) ${ }^{9}$, menyatakan bahwa tidak ada hubungan yang bermakna antara umur ibu hamil dengan kejadian anemia. Anemia defisiensi zat besi pada ibu hamil disebabkan oleh perubahan fisiologi pada sistem kardiovaskuler yang mengakibatkan pengenceran darah. Dalam kondisi tersebut tubuh ibu hamil memerlukan pasokan zat besi untuk memenuhi kebutuhan nutrisi janin dan ibu. Hal ini sesuai dengan hasil penelitian Yuliana Dafroyati (2012) ${ }^{10}$ yang telah dilakukan menunjukkan bahwa $50 \%$ ibu hamil yang menderita anemia hamil pada usia yang tidak beresiko yaitu umur 2035 tahun, dan $50 \%$ ibu hamil pada usia yang beresiko yaitu $<20$ tahun dan $>35$ tahun. Hal ini disebabkan karena umur bukan satusatunya faktor penyebab anemia melainkan ada faktor lain yaitu faktor dasar (sosial ekonomi, pengetahuan, pendidikan dan budaya) dan faktor langsung (pola konsumsi tablet $\mathrm{Fe}$, penyakit infeksi dan perdarahan).

\section{Hubungan Pendidikan dengan kejadian Anemia}

Hasil uji statistik diperoleh nilai Pvalue $=0,491 \quad(\mathrm{p}>0,05)$ berarti tidak terdapat hubungan pendidikan dengan kejadian anemia pada ibu hamil. Hal ini didukung oleh penelitian yang dilakukan oleh Khadijah, (2010 $)^{11}$ dimana dalam penelitiannya diperoleh hasil bahwa ibu-ibu yang berpendidikan sekolah menengah yang lebih banyak mengalami anemia. Namun demikian tidak terdapat perbedaan yang bermakna dalam tahap pendidikan dengan terjadinya anemia. Hal ini mungkin dikarenakan ibu-ibu telah mempunyai pengetahuan akan pentingnya zat besi tanpa tahap pendidikan. Di samping itu, setiap kali mendapatkan pelayanan kesehatan, para tenaga kesehatan memberikan pengarahan tentang hal-hal yang berkaitan dengan anemia ibu hamil.

\section{Hubungan Gravida dengan Kejadian Anemia}

Hasil penelitian dari 39 responden penelitian diketahui ibu hamil trimester III yang mengalami anemia ringan persentase terbesar terdapat pada multigravida yaitu sebanyak 28 responden $(93,3 \%)$. Berdasarkan hasil analisis Chi Square diperoleh nilai p-value sebesar 0,661 $(\mathrm{p}>0,05)$. berarti tidak ada hubungan antara gravida ibu dengan kejadian anemia pada ibu hamil trimester III. Hal ini dikarenakan proporsi sampelnya tidak seimbang dimana proporsi paling besar ialah dari usia multigravida yaitu sebanyak 30 reponden $(76,9 \%)$. Hasil penelitian ini sejalan dengan hasil penelitian Herawati dan Astuti (2010) ${ }^{12}$ yang menyatakan bahwa pada ibu multigravida sebagian besar responden mengalami anemia gizi.Kelompok ibu hamil yang multigravida memiliki kemungkinan mengalami anemia. Hal ini sesuai dengan penelitian Cut Mutiara dkk. (2012) ${ }^{13}$ yang menjelaskan bahwa kejadian anemia pada kehamilan akan meningkat seiring dengan tingginya gravida. Multigravida dapat menyebabkan anemia akibat cadangan besi yang berkurang akibat penggunaan untuk kehamilan sebelumnya belum cukup untuk memenuhi kebutuhan kehamilan sekarang. Hasil penelitian ini serupa dengan hasil penelitian di Malaysia yang melaporkan bahwa sebanyak $60 \%$ perempuan hamil yang 
menderita anemia adalah multigravida. anemia sebesar 1.289 kali dibandingkan kelompok ibu primigravida.

\section{Hubungan Paritas dengan Kejadian Anemia}

Hasil penelitian dari 39 responden penelitian diketahui ibu hamil trimester III yang mengalami anemia ringan persentase terbesar terdapat pada multipara yaitu sebanyak 20 responden $(90,0 \%)$. Berdasarkan hasil analisis Chi Square diperoleh nilai $p$-value sebesar 0,784 $(p>0,05)$. berarti tidak ada hubungan antara paritas ibu dengan kejadian anemia pada ibu hamil trimester III. Hal ini dikarenakan proporsi sampelnya tidak seimbang dimana proporsi paling besar ialah dari multipara sebanyak 22 reponden (56,4\%). Hasil penelitian ini sejalan dengan hasil penelitian Ariyani (2016) $)^{14}$ bahwa dari 45 subjek penelitian diketahui proporsi ibu hamil trimester III yang mengalami anemia persentase terbesar terdapat pada jumlah paritas aman yaitu sebanyak 27 responden $(62,8 \%)$. Berdasarkan hasil uji data statistik menggunakan uji korelasi Rank Spearman diperoleh nilai $\mathrm{p}=0,473$, hal ini menunjukkan bahwa $\mathrm{p}>0,05$ yang berarti tidak ada hubungan yang bermakna antara jumlah paritas dengan kejadian anemia pada ibu hamil trimester III.

\section{Hubungan Ekonomi dengan Kejadian Anemia}

Berdasarkan hasil penelitian kejadian anemia ringan dalam kehamilan terdapat pada ibu hamil dengan penghasilan di atas UMK 13 orang (100\%). Hasil penelitian menunjukkan bahwa tidak ada hubungan yang signifikan antara ekonomi dengan kejadian anemia pada ibu hamil. Penelitian ini sejalan dengan penelitian yang telah dilakukan oleh Ugi Sugiarsih dkk. (2013) ${ }^{15}$ bahwa status ekonomi tidak terbukti mempengaruhi keadaan hemoglobin pada ibu hamil, karena ibu hamil dengan penghasilan yang tinggi belum tentu memiliki pengetahuan tentang makanan yang menjadi sumber zat besi untuk mencegah anemia. Hasil penelitian ini tidak sejalan dengan penelitian yang dilakukan oleh Yanti, D, dkk $(2015)^{5}$, menyatakan bahwa berdasarkan hasil uji chi-square yang di lihat pada hasil fisher's Exact Test diketahui bahwa p-value yaitu 0,000 lebih kecil dari 0,05 (p-value < á), sehingga Ha diterima. Hal ini menunjukkan bahwa ada hubungan status ekonomi dengan kejadian anemia ibu primigravida di wilayah kerja Puskesmas Pringsewu Lampung Tahun 2015.

\section{Hubungan Konsumsi Tablet Fe dengan Kejadian Anemia}

Hasil penelitian dari 39 responden penelitian diketahui ibu hamil trimester III yang mengalami anemia ringan persentase terbesar terdapat pada ibu yang mengkonsumsi tablet besi tidak patuh yaitu sebanyak 2 responden (100,0\%). Berdasarkan hasil analisis Chi Square diperoleh nilai $p$-value sebesar 0,675 $(\mathrm{p}>0,05)$. berarti tidak ada hubungan antara konsumsi tablet besi dengan kejadian anemia pada ibu hamil trimester III.

Penelitian ini bertentangan dengan hasil penelitian Milah, A $(2018)^{16}$ dalam penelitiannya menemukan bahwa berdasarkan hasil uji statistik dengan menggunakan chi square diperoleh nilai $\mathrm{p}=$ 0,002 dengan menggunakan $\alpha=0,05$, maka nilai $\mathrm{p} \leq \alpha$, maka dapat disimpulkan $\mathrm{Ha}$ diterima berarti terdapat hubungan yang signifikan antara konsumsi tablet tambah darah dengan kejadian anemia pada ibu hamil.

Bentuk zat besi yang terdapat dalam tablet fe dan rendahnya zat besi dalam makanan mempengaruhi penyerapan zat besi oleh tubuh. Ada dua macam zat besi dalam makanan, yaitu hem dan nonhem. Zat besi hem berasal dari hewan, penyerapannya tidak tergantung pada jenis makanan lain dan lebih mudah diserap dibanding zat besi nonhem. Pada umumnya zat besi nonhem terdapat pada pangan nabati seperti pada sayur-sayuran, biji-bijian dan buah-buahan Penyerapan zat besi nonhem termasuk rendah dan sangat tergantung pada jenis makanan lain atau menu yang bervariasi. Penyerapan zat besi nonhem dipengaruhi oleh faktor penghambat maupun faktor pendorong, sedangkan zat besi hem tidak ${ }^{17}$. Konsumsi pangan sumber zat besi dan sam folat bisa seperti tempe dan tahu. mengkonsumsi pangan sumber zat besi dan asam folat namun berasal dari sumber nabati $^{18}$. Asam aksorbat (vitamin C) dan 
daging adalah faktor utama yang mendorong penyerapan zat besi nonhem sedangkan yang termasuk faktor penghambat diantaranya adalah keadaan basa pada lambung karena kurangnya asam hidroklorat atau adanya antasid complexing agent seperti fitat (dalam kacang-kacangan, biji-bijian, kedelai dan produknya), oksalat (dalam sayuran) fosfat, tanin (dalam teh) posfitin (dalam kuning telur), beberapa jenis serat makanan, garam kalsium posfat dan protein kedelai yang dapat membentuk senyawa tidak mudah larut sehingga sulit diserap tubuh. Untuk itu vitamin $\mathrm{C}$ sangat berperan dalam meningkatkan penyerapan zat besi dalam tubuh. Peningkatan konsumsi vitamin C sebanyak 25-250 mg dapat memperbesar penyerapan zat besi 2-5 kali. Sedangkan konsumsi bahan pangan yang mengandung zat penghambat seperti teh dan lain-lain harus dikurangi karena zat tersebut akan membentuk senyawa yang tak larut dalam air sehingga tidak dapat diabsorpsi ${ }^{17}$.

\section{KESIMPULAN DAN SARAN}

Berdasarkan hasil penelitian tidak terdapat hubungan yang signifikan antara umur, pendidikan, gravida, paritas, ekonomi, konsumsi tablet besi dengan kejadian anemia pada ibu hamil timester III. Penelitian ini menyarankan bagi tenaga kesehatan lebih menekankan perhatian pada ibu hamil dalam melaksanakan deteksi dini resiko tinggi pada ibu hamil sedini mungkin seperti kegiatan penyuluhan secara rutin umtuk meningkatkan pengetahuan dan kesadaran tentang adanya resiko tinggi dalam kehamilan.

\section{UCAPAN TERIMA KASIH}

Peneliti mengucapkan terima kasih kepada Kepala Puskesmas Mapane dan Bidan Koordinator yang telah memberikan izin dan membantu dalam proses penelitian ini.

\section{DAFTAR PUSTAKA}

1. Camaschella, Clara. 2015. "Iron-Deficiency Anemia." Iron-Deficiency Anemia 372: 1832-43.

2. Mandang, J, Dkk. 2016. Asuhan Kebidanan
Kehamilan. Bogor: In Media.

3. Wiknjosastro H. 2012. Ilmu Kebidanan. Jakarta: Yayasan Bina Pustaka.

4. Amartami R, Frelestanty E, Haryanti Y, Masan L. Faktor-Faktor Yang Berhubungan Dengan Kejadian Anemia Pada Ibu Hamil. J Kebidanan-ISSN 2252-8121. 2017;7(2):140147.

5. Ari D, Sukistianingsih A, Keisnawati. FaktorFaktor Terjadinya Anemia Pada Ibu Primigravida di Wilayah Kerja Puskesmas Pringsewu Lampung. J Keperawatan. 2015;6(2):79-87.

6. World Health Organization. The Global Prevalence Of Anemia In 2011.; 2015.

7. Kemenkes RI. Profil Kesehatan Indonesia Tahun 2013. Jakarta; 2017.

8. Dinas Kesehatan Kabupaten Poso. Laporan Tahunan Kesehatan Ibu Dan Anak.; 2018.

9. Simbolon M. Faktor-Faktor Yang Berhubungan Dengan Kejadian Anemia Pada Ibu Hamil Di Puskesmas Maubesikabupaten Timor Tengah Utara Tahun 2018. 2018:36-45.

10. Dafroyati Y. Faktor-Faktor Yang Mempengaruhi Kejadian Anemia Pada Ibu Hamil Di Puskesmas Sikumana Kota Kupang Tahun 2012. 2012;11(2):468-480.

11. Siti Khadijah. Hubungan anemia dan usia pada ibu hamil dengan kejadian abortus inkomplit di rsam bukittinggi. J Endur. 2017;1(October 2016):158-166.

12. Herawati, C \& Astuti S. Faktor-Faktor Yang Berhubungan Dengan Anemia Gizi P Ada Ibu Hamil Di Puskesmas Jalaksana Kuningan Tahun 2010. J Kesehat Kartika. 2010:51-58.

13. Sabrina $\mathrm{Cm}$, Serudji J, Almurdi. Gambaran Anemia Pada Kehamilan Di Bagian Obstetri Dan Ginekologi Rsup Dr . M . Djamil Padang Periode 1 Januari 2012. J Kesehat Andalas. 2012;6(1):142-146.

14. Ariyani R. Faktor-Faktor Yang Mempengaruhi Kejadian Anemia Pada Ibu Hamil Trimester Iii Di Wilayah Kerja Puskesmas Mojolaban Kabupaten Sukoharjo. 2016;23(45):5-24.

15. Sugiarsih U. Hubungan Tingkat Sosial Ekonomi Dengan Kadar Haemoglobin. J Kesehat Reproduksi. 2013;4(2 Ags):73-79. doi:10.22435/jkr.v4i2Ags.3905.73-79

16. Ana Samiatul Milah. Hubungan Konsumsi Tablet Fe Dengan Kejadian Anemia Pada Ibu Hamil Di Desa Baregbeg Wilayah Kerja Puskesmas Baregbeg Kabupaten Ciamis Tahun 2018. J Keperawatan Galuh. 2016;1(1):12-36.

17. Sediaoetama. Ilmu Gizi. Jakarta: Dian Rakyat; 2009.

18. Suastira S, Sumiaty S, Ansar A. Konsumsi Pangan Sumber Zat Besi Dan Asam Folat Dengan Anemia Pada Ibu Hamil Di 
Puskesmas Tawaeli. J Bidan Cerdas JBC [Internet]. 2018 Nov 26 [cited 2019 Oct 20];1(1):9. Available from: http://jurnal.poltekkespalu.ac.id/index.php/JB C/article/view/82 